Revista Eletrônica Geografar, Curitiba, v. 2, Resumos do VI Seminário Interno de Pós-Graduação em Geografia, p. 43-43. Junho/2007

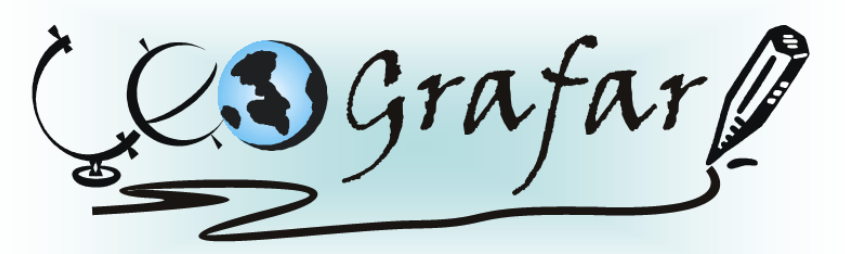

Revista Eletrônica do Programa de Pós-Graduação em Geografia - UFPR

\title{
ANÁLISE COMPARATIVA DA TERRITORIALIDADE DO TURISMO NOS PARQUES ESTADUAIS DE IBITIPOCA - MG E VILA VELHA - PR
}

\section{LEANDRO MARTINS FONTOURA ${ }^{1}$}

O trabalho propõe a análise territorial de espaços utilizados pelo turismo, apresentando e discutindo paralelamente os impactos ambientais percebidos em unidades de conservação que tenham fluxo turístico.Utilizando-se da implantação do plano de manejo, objetiva-se discutir a sua interferência nos modos de gestão e ordenamento territorial dos parques. Para concretizar esta análise será realizado um estudo comparativo entre as realidades encontradas nos Parques Estaduais de Vila Velha (PR) e Ibitipoca (MG). Considerando que o parque paranaense já possui plano de manejo implementado e ambos possuem características semelhantes, procura-se estabelecer relações que auxiliem no processo de planejamento do parque estadual de Ibitipoca. Para concretizar esta finalidade propõe-se o método de análise territorial do turismo apresentado por Vera (1997) e adaptado para o estudo de unidades de conservação. Analisando-se os modos de gestão e impactos ambientais provenientes do turismo, a estrutura mais adequada foi a realização do método de amostragem crítica, utilizando-se de entrevistas com informantes qualificados. Essa metodologia pode informar de maneira fidedigna quais são as ferramentas utilizadas na gestão do turismo em unidades de conservação, principalmente a partir da implementação do plano de manejo dos parques. O segundo aspecto metodológico aborda a seleção e procedimentos para coleta de dados de campo, no que concerne aos impactos ambientais registrados em função da utilização ostensiva do turismo nas unidades de conservação estudadas. Para isso a técnica utilizada será a Observação Estruturada. Feita a correlação dos dados através do coeficiente de Pearson e a elaboração da análise comparativa entre os parques, é possível estabelecer diretrizes para a abordagem a nível estratégico dentro das unidades. A intenção da pesquisa é diagnosticar as ameaças, pontos fortes e oportunidades das unidades de conservação, de modo a subsidiar o planejamento territorial do local, especialmente no que tange ao ordenamento turístico.

Palavras-chave: ecoturismo, planejamento ambiental, território.

${ }^{1}$ Mestrando em Geografia - UFPR - email: leandro.fontoura@gmail.com Orientador: MARCOS AURÉLIO TARLOMBANI DA SILVEIRA 